University for Business and Technology in Kosovo

UBT Knowledge Center

UBT International Conference

2018 UBT International Conference

Oct 27th, 9:00 AM - 10:30 AM

\title{
Civic Education Program motivates psycho pedagogic interaction
}

Denis Çelçima

Aleksander Moisiu University, den_english@yahoo.it

Votim Hanoli

Aleksander Moisiu University, votimhanoli@hotmail.com

Follow this and additional works at: https://knowledgecenter.ubt-uni.net/conference

Part of the Education Commons

\section{Recommended Citation}

Çelçima, Denis and Hanoli, Votim, "Civic Education Program motivates psycho pedagogic interaction" (2018). UBT International Conference. 120.

https://knowledgecenter.ubt-uni.net/conference/2018/all-events/120

This Event is brought to you for free and open access by the Publication and Journals at UBT Knowledge Center. It has been accepted for inclusion in UBT International Conference by an authorized administrator of UBT Knowledge Center. For more information, please contact knowledge.center@ubt-uni.net. 


\title{
Civic Education Program, motivates psycho pedagogic interaction
}

\author{
Denis Çelçima ${ }^{1}$, Votim Hanoli ${ }^{2}$ \\ Aleksander Moisiu University, Durres, Albania. \\ den_english@yahoo.it ${ }^{1}$, votimhanoli@ hotmail.com $^{2}$
}

\begin{abstract}
The proper method of psychological treatment of the problem of academic formation and student citizenship, which may be recommended for all levels of guidance and teaching in our school, orientates the use of three practical tips for an accepted and more mature change quick change will take more time to absorb. Big mistakes cannot be repaired easily. In a wider context, many of the various analyzes that have been carried out so far in the state of the education system, we must admit that a delicate and distinctive feature emerges in this delicate and important field of life in the country. Such phases of psychological treatment of the problems of change and restructuring of the education system have, in their majority, been disconnected from one another. For political reasons, they often surprised the civic opinion and the school itself, stressed the pedagogical body, creating a situation of anxiety and insecurity. The consequences have directly affected the effectiveness of the changes. Can we say, "... we are successful and on the road ..."! If there is something in common in the noble profession of teachers, it is the deep knowledge, methodology and methodology, which represent their generalization values, as well as exhibit professional individuality in the interest of the qualitative growth of teaching. Achieving the method is not easy, as it seeks the support of many other elements as personal attributes of teachers, related to language formation, scientific terms of study, knowledge of general formation on the basis of new information, the way of communication, patriotism, formation on national and historical values, recognition of tradition, etc. all for the developing of the personal skills of student learning within a complex space created by the need to build curricula throughout the annual academic training cycle. In this context, the course on civic education in high school combines and manages to naturally integrate all the knowledge gained in other subjects of the curriculum.
\end{abstract}

Key words: pedagogical method, teacher, adolescent, civic education 


\section{Psychopedagogical method and methodology in civic education}

The proper method of psychological treatment of the problem of academic outreach and student citizenship, which may be recommended for all levels of guidance and teaching in our school, guides the use of practical triangles for an accepted and more mature change:

* To distinguish between change, the personal softening and professional controversies of "people" (important, key) should be foreseen.

* A profound change will never have to come as a wonder and as much as possible to surprise the participants, but as a rational need of time.

* Never do we have to change things a lot and very quickly, (with blow).

Quick change will take more time to absorb. Big mistakes cannot be repaired easily. In a wider context, many of the various analyzes that have been carried out so far in the state of the education system, we must admit that a delicate and distinctive feature emerges in this delicate and important field of life in the country. Such phases of psychological treatment of the problems of change and restructuring of the education system have, for the most part, been disconnected from one another. For political reasons, they often surprised the civic opinion and the school itself, stressed the pedagogical body, creating a situation of anxiety and insecurity. The consequences have directly affected the effectiveness of the changes. That's not the case to say that, "... we are successful and on the right track ..."! If there is something in common in the noble profession of teachers, it is the deep knowledge, methodology and methodology, which represent their general values, as well as exhibit professional individuality in the interest of the qualitative growth of teaching. This logical and study perspective, in general and detailed lines, precisely determines the main lines of the teaching method, based on the rankings and the quality of the selected topics, enabling new experiences.

Scientific research method, successfully applied throughout the process of granting and assimilating program themes and concrete results, is built on the basis of collaboration and interaction, based on a systematic work of documenting the results. Scientific research methodology, evidence and research in the interesting field of civic education of students, as one of the most difficult and serious commitments in the teacher's mission, through analysis and criticism, enables the achievement of new knowledge and experiences in teaching, which take their general character.

On these methodological recommendations, the subject of civic education of students at secondary school takes its theoretical, practical and applicative importance, combined with the new ones stemming from the observance of time standards, which create spaces for alternative variables in the judgment and decisionmaking of the teacher. The basic method is the critical analysis of what we have done well in the civic education of students and the other, towards the failure, so that we can 
meet the objectives of the citizenship program, to concretize these theoretical notions in the real environment of our school.

In school, in terms of implementing ethical norms of civic behavior and education, many students appear to be dressed and behave inappropriately, becoming the object not only of attracting young people, but sometimes teachers. One more concern, left suspended, though sometimes it poses as a social and psychological nuisance. Teachers are the first to talk about this problem and to argue ways of solving or minimizing the phenomena that have implications for the teaching and education process. From surveys conducted in high schools, "nearly 92 percent of teachers think that in schools, a uniform format for students should be introduced, under conditions set by the institution." So, dressing the students is not left to wishes and spontaneity. Although we may think that this is "an individual" case we should admit that the pedagogical criteria, pedagogical norms and ethics, cannot accept that student dressing is a cause for unusual occurrences of self-sufficiency, which may cause another phenomena: the temptation. This applies both for girls, as well as for boys.

In psychological terms, the attraction of extravagant clothing and other overlapping ornamentation, the distinctive religious mark, are external factors that influence student behavior. They have side-effects in their consciousness. Attribution and the coverage of the case belongs to external factors. The social cognition of students cannot be well functioned. Often, they become prone to self-misunderstanding and peers. Everything that fosters an inappropriate outfit makes the student object to prejudice, critics and his failures in other directions. Psychological protection mechanisms are often lacking. Encouraging emotional emotions, avoids the ability to concentrate on the main task for which the student is at school. There are different opinions, some of them see the dressing not as a school problem, but as a problem for the person and family. There may seem to be a tendency to reconcile with this finding, but in essence, in the conditions in which school discipline now appears, the lack of civic culture, self-perpetuation and other psychological action elements does not relieve the responsibility of the family either school, but the individual, who is prepared with negative differences for life and society. There are other opinions that think that the problem does not lie in dressing but in the backward mentality, in the lack of culture, and in the psychological and social preparation of young people, with the effects and impacts that the dressing upon man is.

Example: "Every state or private institution has its own rules in clothing and behavior. In a school bank you cannot wear extravagant clothes, and as we see commonly see. Workers dressed in costume look beautiful. The school has its own rules too. When a teacher rebuked a girl because she did not answer in the lesson ... she began to cry and the eyeliner began to flow too ... this is not appropriate. "

In this case, there are also extremist attitudes, where the timing of the movement is lacking. To politicize this problem, because of a past, where school uniforms were a compulsion, is a wrong attitude. Far from politicization, today in Western experience, there are many educational institutions that have put the rule of external appearance at school, and have not seen anything wrong with this action, on the contrary. So, are our social relationships harmonized in our school with individual 
ones? What forces school teachers who are nearly unanimous in their opinion of using a school uniform? What do they find and what they think about the school environment? Are not these our teachers who have the responsibility of preparing for the younger generation, who more than others should be listened to? What is the importance that the problem takes in theory, when practically the teachers are nearly helpless in changing the situation, even though they consume much of themselves in the interest of student education?

Theoretical importance cannot be considered, "theories are theories, it's enough fulfilling the program", but it stands in the ability to predict a qualitative element of theoretical and practical treatment of citizenship, which attracts students into the citizen education process, not only within the framework of the program, but with the opportunity to expand the knowledge on Civic Ethics and Behavior in relation to the school and social environment.

The practical significance lies in the expectations of the conclusions from year to year, respecting the critical thinking of teachers and students, which help with new experiences in upgrading the methodology of realization of the subject of civic education, bringing the satisfaction of maximum achievement in student assessment.

This theoretical and practical summary can be presented like this:

* Possible typological and psychological categorization of students, to facilitate their work on selecting themes and how to handle them;

* Selection of learning outcomes for key, complex, and relevant competencies, defining shortcomings and priorities;

* Keeping in mind the learning outcomes for the key competency categories for each academic year (especially the previous one), which will serve to increase the level of knowledge in civic education and increase key competencies;

* Selection of learning outcomes for each element of key competences in the field of civic education and determination of goals in assimilation and psycho-social and academic achievement of students;

* Selection of the program and the content of the lesson, its means of materialization, teaching methodology, comparison and dealing with situations inside and outside the school, where through these elements the teacher achieves the anticipated learning outcomes in increasing citizenship competences in the academic year, compared and faced with key competencies in student formation.

* The curriculum at a well-planned time frame, on the effective teaching of the internal causal connection of the subject, by laying sound grounds on the learning outcomes of the students

* Realization of student achievement analysis based on the analytical method after completing the program's hours, complementary tasks, tests, surveys and semistructured interviews, by verifying the achievement of learning outcomes, progress of the implementation of the annual program of the subject of civic education.

In high school, the annual program contains 72 hours, 5 themes, which create conditions for students to build sustainable knowledge and apply this knowledge, the skills, values in function of core competencies and key competencies. Based on the 5 themes of the program, the student book and the teacher's booklet have been designed to provide in an organized way, step by step, the treatment of the teaching situation 
according to their themes in their value growth. They are focused on their component elements in the function of civic education, relying on: learning outcomes according to key competencies and citizenship competence, in annual lessons organized according to topics, in the three-month curriculum, the classroom for each lesson, etc.

\section{Alternative study method}

This summary can be evaluated as a goal aimed at educating students through the decomposition of program elements based on the use of interactive methods, techniques and strategies that create harmonious cooperation between teaching and learning. In this complex process, the realization of the general and specific objectives of education are interlinked, mainly based on the education of human rights and fundamental freedom, cultural, humanitarian and peace education elements, general education with global concepts, respecting and convey the educational values of the media, the environment, criminal and road codes, the way of economic treatment, security norms, etc.

\section{Alternative Methods for Implementing Citizenship Education Program}

This program remains an open-minded element of civic formation, and as such, it does not easily accept the traditional forms of teaching and learning, where the role of the teacher appears simply as a transmitter of knowledge, and the learner may be a passive listener. The methodical process remains open to the application of alternative methods, which finds space within time requirements and causal relationship with the curriculum. Drawing on the practical plan of implementation of the program, we will give in detail some elements which should be respected. The content of the civic education program offers numerous opportunities for teachers to develop lessons based on; active interaction between teachers and students; in the use of personal experiences of students; in encouraging students to select their own strategies, based on the individual skills of intelligence; in the effective participation of students in teaching activities; their independence in the free expression of ideas and personal opinions as well as the use of the didactic tools necessary for the normal development of the program. Civic Education Program Motivates Effective Interaction between Students and Teachers, Between Small Businesses and Major Groups, between Independent Work and Interaction. In this context, priority is given to the respect of the program standards and the alternative orientation to stimulate different ideas arising from the active participation of students in the classroom, their critical reflection on the reality and the quality of theoretical practical reference concepts of the subject.

Significance in this complex process gets the product of activities that can be prepared by students in the classroom, such as posters, different mental structures in white papers, various papers, or reflections written on various issues of education. Productivity of students is the most qualitative indicator of the perfection and implementation of their civic education program. Objectives and goals are evaluated at 
the top level compared to other subjects. Their content extends beyond the curriculum limitations and the presence and impact of traditional school structures. She pleasantly breaks the "discipline" in our classes. It asks and accepts debate, liveliness, attitudes, display of opinions, diverse views of students.

Achieving the method is not easy, as it seeks the support of many other elements as personal attributes of teachers, related to language formation, scientific terms of study, knowledge of general formation on the basis of new information, the way of communication, patriotism, education on national and historical values, recognition of tradition, etc. all in face of the personal skills of student learning within a complex space created by the need to build the curricula throughout the annual academic training cycle. In this context, the course on civic education in high school combines and manages to naturally integrate all the knowledge gained in other subjects of the curriculum. Another aspect of the methodology in its elaboration is the space for teaching lessons into the student's personal experiences, the various events they have experienced in the community they belong to, as concrete case studies by teachers for new curriculum topics of interest, which best meet the self-actualization of the classroom and the objective that aims to fill it.

The study space, both the flow and product of students' engagement in their lesson, their demands and experiences, serve as a linkage bridge between theory and practice, the basis for the formation of students in school, strongly linked to real life. This way of interaction and enrichment in the citizenship program will naturally reflect on their positive attitude to school and life because they feel respected within the social group, in the growing thoughts and tendencies of their civic behavior. Teachers can use and develop different methods in their teaching, but the civic education program requires the planning and development of an interactive teaching, which is based on teacher-student interaction, physical environment, didactic, and student materials, such as and numerous products designed and prepared by the students themselves, where group work is important, coupled with independent work and individual work. In this regard, we will also look at an issue related to the growth of the culture level that follows the curriculum on civic education. The period of use of computer tools, in the quality of education and civic education and culture, has brought another consequence, which has to do with the writing of students and teachers and the use of graphology. Using the keyboard is replacing handwriting. The glitter has lost its appearance. The high school students who can write beautifully are diminishing every day and this phenomenon is apparently not a primary subject of the teaching. Often, teachers themselves are forced to "eject" the sites that are required to read with the writing of students. More stress, forces them under the influence of doses of nervousness and fatigue, to make undeserved mistakes and punishments. The writing psychology features two sides of its display, the side of content and appearance. The teacher should be able to explain and persuade this matter, in the technical views of the problem. Even in this matter, teachers will have to evolve into the soul of the student by creating trustful relationships. If we want to provide the necessary education, it will be difficult if we do not know the psychic scheme in adolescents, which appear in their "plastic" form, where the possibility of removing excess parts reveals one formed personality. The automation of a handwriting, the look of the script that is perceived, the links between the insides and the insights into the student's sub consciousness, all the psychological characteristics associated with the degree of intellect. The beautiful-writing model and 
the shaping power of writing, express the opposite sides as part of the personality of the student and the teacher.

One more problem for teachers and students who are subject to this analysis is in the displaying of their graphology. As the age of children in adolescence increases, "a psychodynamic test of their personality is taught." And if the disregard of a bad writing can be passed easily and perhaps unnoticed, the student's essential equipment with the general culture of education, it is not a phenomenon that may be lost as easily in the psychoanalysis of the teacher and students. Writing is a special form of personal competence related to the individual's external behavior, the increase of his cultural level, a manifestation of the psychic dynamism of the subject, an expression of character, degree of intelligence and personality.

\section{What should we change in the method of civic education?}

The roles and competences that teachers and students have traditionally succeeded in, today should really need to be changed. Integrated Intermediate Knowledge versus Restricted Knowledge, subjects, theories and issues related to nature and human development; adaptation of different learning avenues to achieve special educational goals, such as the field of behavior, knowledge and humanity, the principles of the teaching and learning process, and the organization and administration of group activities. Changes also relate to the process of manifold and dynamic teaching, as opposed to its linear and static process, in all its dimensions, singling out; processing and defining the diversified objectives; elastic management of teaching groups and groups; the variety of teaching models, through open learning and collaboration, as well as mutual evaluation. Changes relate to multiple educational goals, as opposed to those limited in the field of knowledge. Bear in mind the complexity and the changes that take place in today's world and rely on individual engagement, to improve living conditions and to master the habits of action. In this context, one of the most important requirements in the field of teaching is the teachers' conviction in the ability of the learners to learn and that they are capable of teaching or helping them to learn. Learning about the new elements of democratic citizenship includes other teaching skills that are important for the process of enabling students to become responsible citizens.

The new elements aim at enhancing the ability to look at problems from a student's point of view, taking into account his background, age, and educational level, as well as the ability not to prejudice attitudes and perceptions that are different from his own. They aim to increase the ability to understand, accept and respect the similarities and differences that exist between teachers and students as well as between students. This is based on respect for students' rights and sensitivity to their needs and interests. They aim to increase the ability to handle controversial issues and to cope with problematic and complex situations that may arise in the school environment. They aim at the ability to see themselves and their students as active participants in the local, national and international community. Obedience to the prospect of progress that each individual achieves can help to achieve this goal. They aim at increasing the ability to integrate personal priorities into a common set of problems and values and to apply the decisions taken by the learner in practice. Willingness to accept mistakes before the group and draw lessons from them, the ability to openly perceive and debate about the 
problems posed by the underlying curriculum increases the integration values into teacher-student relationships to a considerable degree. In the end, evaluating the pedagogical logic and the selected methodology, under changing conditions, we respect the "golden middle", which harmonizes the extremes and creates an educational and acceptable environment for adolescents. The problem is essential: Is there a recommended selection based on real-life studies to find Aristotle's "middle class" high school system, which can lead us to the most acceptable ways to serve the prospect? Determinants of the tested condition are real, operative and should be respected for the purpose of specifying the recommendations, with prevention effects in the interest of civic education. In the whole of the analysis, the real situation forces us to look for ways to overcome contradictions in the system of academic formation and civic education. Without respecting the action of economic, educational and cultural factors, the impact of the social environment, relations between tradition, inheritance and perspective regarding to the national phenomenon in relationships and interaction with imported phenomena influenced by external factors, we cannot find the desired choices in the interest of strengthening the work on academic formation and civic education of our children. The psycho-pedagogical methodology should go beyond the framework of the recommendations and become a field of exploration, especially for the enhancement of teaching skills. Deductions in this field cannot be given empirically. The changing time implies finding ways that the method and achievements go beyond this imposing frame.

\section{References}

1. Alfred, A. (2010). Underrstanding Human Nature, Të kuptosh natyrën e Njeriut, botim i SHB Fan Noli, Tiranë. p.3, 18.

2. Celcima, D. (2016). Material studimor i mbrotjes së Doktoraturës: Sfidat e Motivimit në Adoleshëncë, UET, Tiranë. p. 127

3. Muka, P. (1995). Mjeshtër Kërkimesh, në vlerësim të botimit: Myra Pollack Sadker, David Miller Sadker, Mesuesit, shkolla dhe shoqëria, Përvojë amerikane bashkëkohore - një mundësi më shumë në procesin e reformimit të shkollës tonë. Tiranë "Eureka". p.4

4. Erikson, E. (1968). Identity: Youth and crisis. Identity and the Life Cycle. [International Universities Press]. New York: Norton. p.297

5. Keniston. (1977). Youth: A "new" stage of life. American Scholar, 39. Lipsitz. p.631 $-641$.

6. Le Bon, G. (2001). Psikologiia e Rracave, Shtëpia Botuese Reklama, Tiranë p.3.

7. Bardhyl, M. (1999). Psikologiia e Edukimit, Shtëpia Botuese PEGI, Tiranë. p.89.

8. Sadker, P. M., \& Sadker, M. D. (1995). Mesuesit, shkolla dhe shoqëria, Përvojë amerikane bashkëkohore - një mundësi më shumë në procesin e reformimit të shkollës tonë. Tiranë "Eureka". p. 214.

9. Steinberg L. (1999), Adolescence. Fifth Edition. McGraw - Hill, p. 10.

10. Steinberg, L., \& Levine, A. (1999). You and Your Adolescent: A Parent's Guide for Ages 10 to 20. New York: HarperPerennial. 